\title{
Three new species of eriophyoid mites (Acari, Eriophyoidea) from Xinjiang Uygur Autonomous Region, China
}

\author{
Ji-Wei Li', Zhen-Hui Wang', Xiao-Feng Xue², Jian-Ping Zhang'
}

I Department of Plant Protection, College of Agriculture, Shihezi University, Shihezi, Xinjiang 832000, China 2 Department of Entomology, Nanjing Agricultural University, Nanjing, Jiangsu 210095, China

Corresponding authors: Xiao-Feng Xue (xfxue@njau.edu.cn); Jian-Ping Zhang (zhjp_agr@shzu.edu.cn)

Academic editor: E. de Lillo | Received 13 November 2014 | Accepted 2 June 2015 | Published 17 June 2015

http://zoobank.org/F8CB095E-BDC0-449D-AB71-8819D04E7862

Citation: Li J-W, Wang Z-H, Xue X-F, Zhang J-P (2015) Three new species of eriophyoid mites (Acari, Eriophyoidea) from Xinjiang Uygur Autonomous Region, China. ZooKeys 508: 97-111. doi: 10.3897/zookeys.508.8940

\begin{abstract}
Three new species of eriophyoid mites from Xinjiang Uygur Autonomous Region, China, are described and illustrated. They are Paracolomerus gonglius sp. n. and Phyllocoptruta beggerianae sp. $\mathbf{n}$. collected on Rosa beggeriana Schrenk ex Fisch. \& C. A. Mey. (Rosaceae), and Rhyncaphytoptus fuyuniensis sp. n. collected on Cotoneaster ignavus E. L. Wolf (Rosaceae). All eriophyoid mites described here are vagrants on the undersurface of leaves and any apparent damage was not observed.
\end{abstract}

\section{Keywords}

Taxonomy, Colomerini, Phyllocoptini, Rhyncaphytoptinae, Rosaceae

\section{Introduction}

Eriophyoid mites (Acari: Eriophyoidea) have been recognized as important pests in agriculture and forestry all over the world (Lindquist et al. 1996). Their stylets are involved in piercing plant cells, injecting saliva into them and sucking cell sap (de Lillo et al. 2002). The saliva causes cytological, biochemical and physiological changes in the pierced plants (de Lillo and Monfreda 2004, Petanović and Kielkiewicz 2010a). 

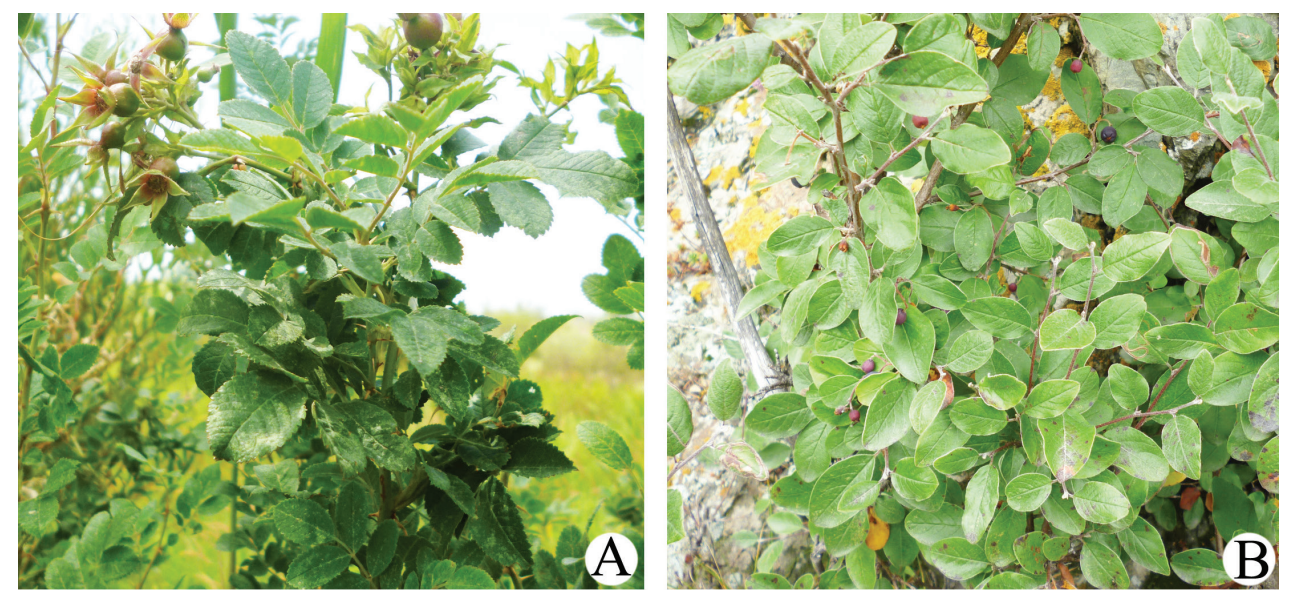

Figure I. A Rosa beggeriana Schrenk ex Fisch. \& C.A. Mey B Cotoneaster ignavus E.L. Wolf.

Eriophyoid mites induce plant malformations as galls, complex symptoms or vector pathogens disturbing the normal growth of plants (Petanović and Kielkiewicz 2010b). This is the case of Colomerus vitis (Pagenstecher), Aceria pallida Keifer and Tegolophus zizyphagus (Keifer) which induce erinea, galls or leaf edge curls and cause economic losses to grape, matrimony vine and jujube, respectively, in Xinjiang (Lu and Mao 1990, Zang 1998, Yang et al. 2012). However, about half eriophyoid mite species are vagrants on the surface of leaves and do not cause any apparent damage (Huang 2008, Skoracka et al. 2010, Petanović and Kielkiewicz 2010b). These mites, occurring in a large amount, may cause non-distortive changes and affect the normal growth of the plants (Oldfield 1996). Usually eriophyoids are tiny in size and hard to see with unaided eyes. Sometimes their symptoms can be confused with those due to viruses, nutrient deficiency and physiological disorders (Van Leeuwen et al. 2010). Therefore, it is necessary to study the systematic account of Eriophyoidea for having a further contribute in better understanding their significance in Agriculture.

Kuang (1995) first explored and reported the eriophyoid mite fauna in Xinjiang. After that, a number of field surveys were conducted in the same area and further 31 species were reported so far. Out of 31 species, 1 species belongs to the family Phytoptidae, 2 species belong to the family Diptilomiopidae and 28 species belong to the family Eriophyidae (Table 1). The fact that more than 1000 species have been recognized from China (personal data of X.-F. Xue) suggests that many more areas need to be explored more carefully. For this purpose eriophyoid mites were collected by Ji-Wei Li from Tianshan Mountains, Altai Mountains, Farmlands and Gurbantunggut Desert of Xinjinag in 2013 and 2014.

In the present study, we describe 2 new species of the genera Paracolomerus and Phyllocoptruta collected on Rosa beggeriana (Fig. 1) and one new species of the genus Rhyncaphytoptus collected on Cotoneaster ignavus (Fig. 1), all from Xinjiang. Also, this is the first description of the genus Paracolomerus from Rosaceae. 


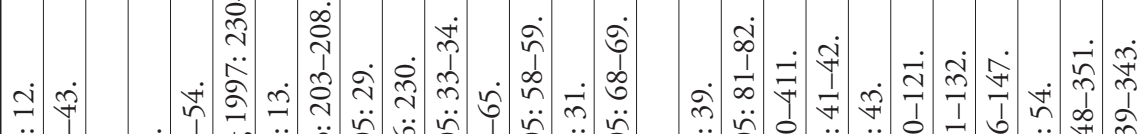

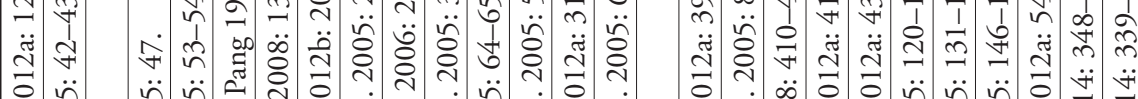

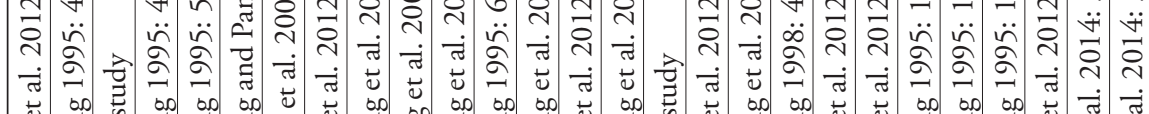

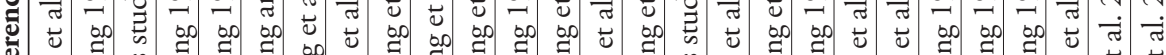

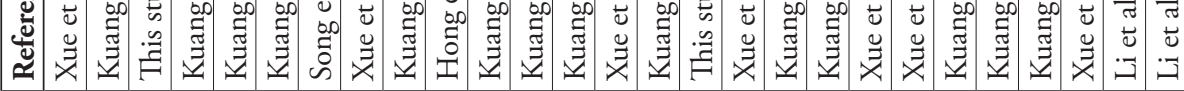

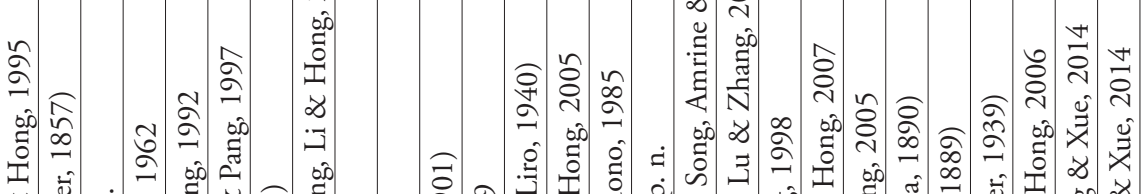

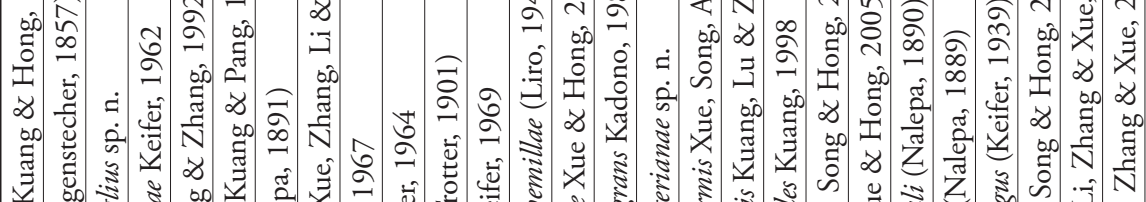

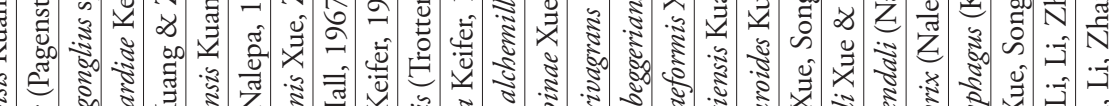

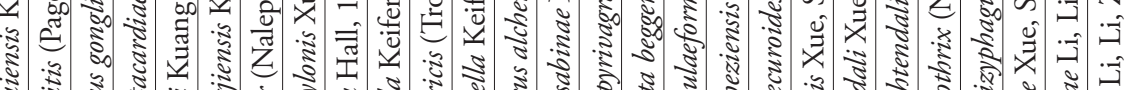

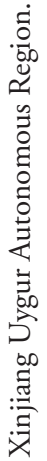

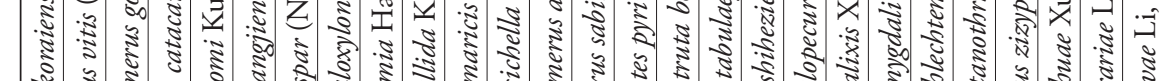

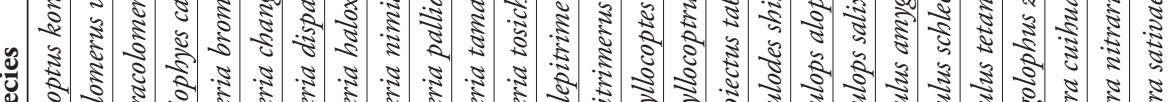

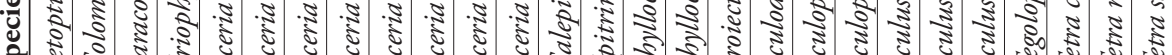
क ज व

9

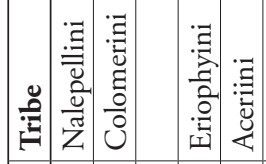

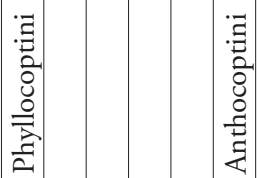




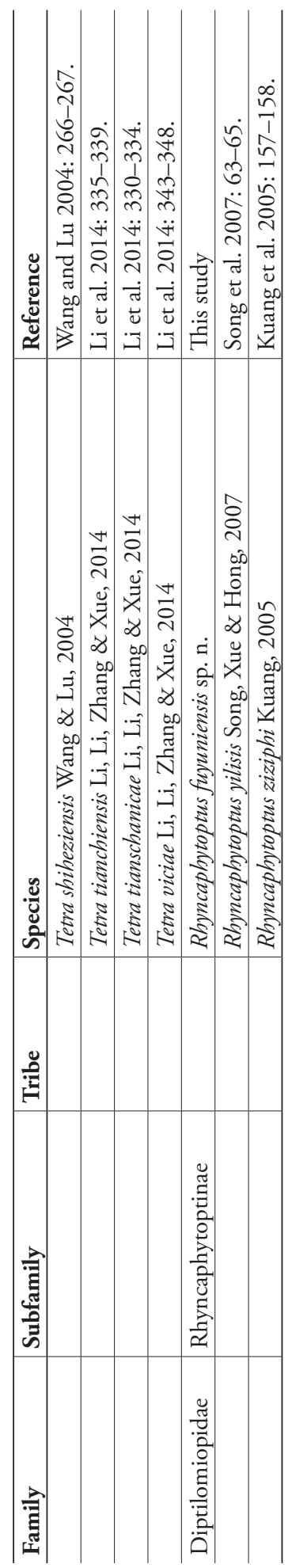




\section{Materials and methods}

Specimens of mites were collected from Xinjiang Uygur Autonomous Region, China. The morphological terminology used here follows Lindquist (1996). The generic classification of the eriophyoid mites is made according to Amrine et al. (2003), together with the comparison of genera erected after 2003. Specimens were cleared in Keifer's booster and slides were mounted using modified Berlese medium (Amrine and Manson 1996). The number of measured specimens (n) is given within parentheses in the description. All specimens were examined, measured, taken photos and drawn with the aid of an Olympus Bx61 microscope using phase contrast. The measurements and drawings were based on the methods outlined by de Lillo et al. (2010) and abbreviations follow Amrine et al. (2003). For each species, the holotype female measurement precedes the corresponding range for paratypes (given in parentheses). For males, only ranges are given. All measurements are given in micrometres and are lengths unless specified. Type specimens are deposited at the Department of Plant Protection, College of Agriculture, Shihezi University, Xinjiang Uygur Autonomous Region, China.

\section{Results}

Family Eriophyidae Nalepa, 1898

Subfamily Cecidophyinae Keifer, 1966

Tribe Colomerini Newkirk \& Keifer, 1975

Genus Paracolomerus Keifer, 1975

\section{Paracolomerus gonglius sp. $\mathbf{n}$.} http://zoobank.org/36D41CF4-E10C-47F1-8635-3E2CC695A2CB

Fig. 2

Description. FEMALE ( $\mathrm{n}=6$ ). Body vermiform, 187 (175-217, excluding gnathosoma), 50 (42-51) wide, 48 (40-47) thick; light yellow. Gnathosoma 24 (23-26), projecting obliquely down, pedipalp coxal setae (ep) 2 (2-3), dorsal pedipalp genual setae (d) 7 (68), unbranched, cheliceral stylets 21 (20-23). Prodorsal shield 30 (29-32), 37 (33-37) wide; median line almost complete, interrupted in the middle with short sloping lines on either side at the posterior end, admedian lines complete, submedian lines broken, with several short lines and granules on the lateral side; frontal shield lobe absent. Scapular tubercles near rear shield margin, 24 (23-24) apart, scapular setae (sc) 15 (14-15), projecting posterior. Coxigenital region with 5 (5-6) microtuberculated semiannuli. Coxal plates with several short lines, anterolateral setae on coxisternum I (1b) 7 (7-8), 11 (1011) apart, proximal setae on coxisternum I (1a) 25 (25-28), 13 (12-13) apart, proximal setae on coxisternum II (2a) 44 (39-44), 24 (23-24) apart, tubercles $1 b$ and $1 a$ apart 5 (5-6), tubercles $1 a$ and $2 a 8$ (7-8) apart. Internal coxisternal apodeme absent. Legs with usual series of setae. Leg I 27 (26-28), femur 8 (7-8), basiventral femoral setae (bv) 12 

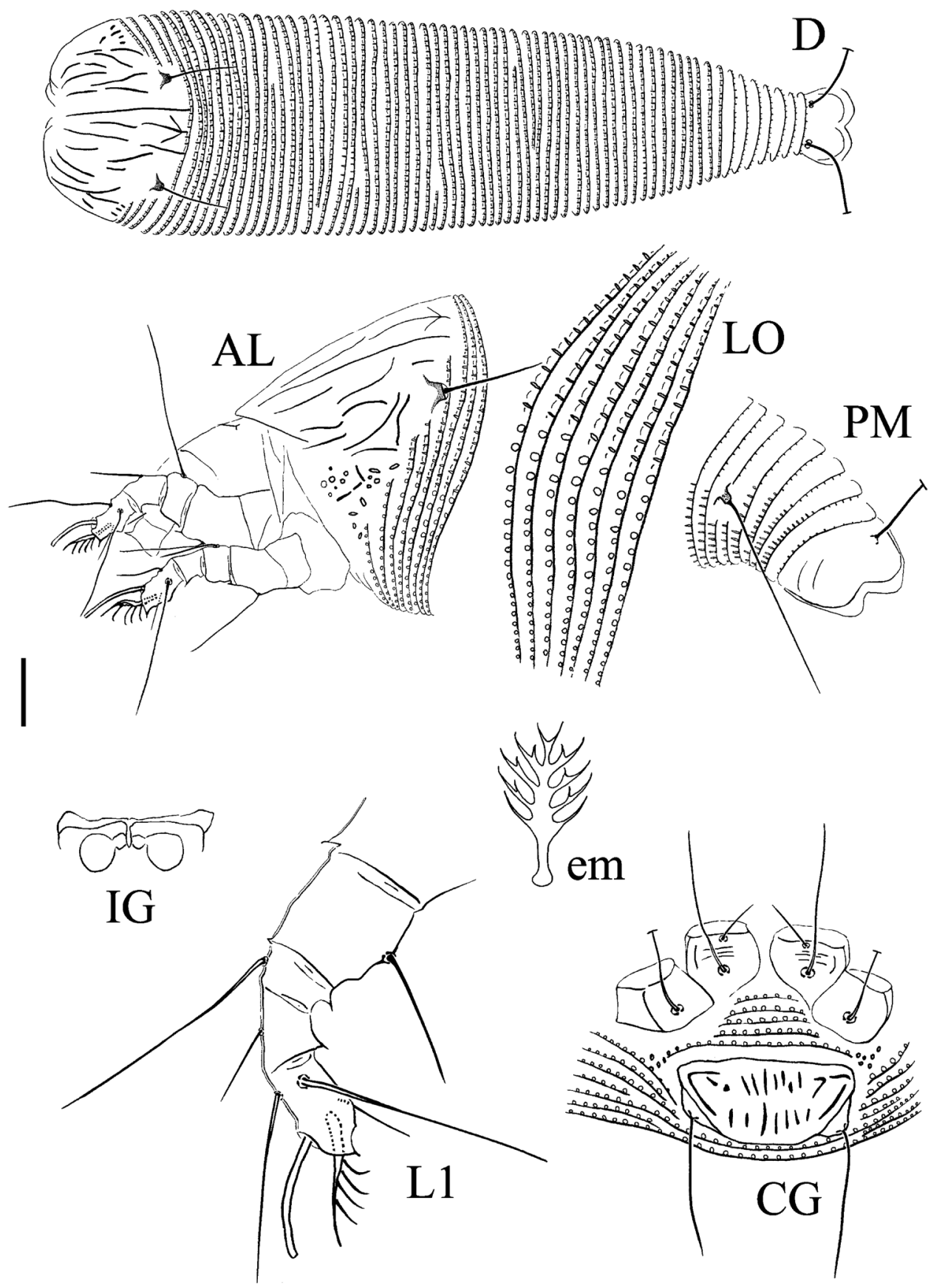

Figure 2. Schematic drawings of Paracolomerus gonglius sp. n.: AL Lateral view of anterior body region CG Female coxigenital region D Dorsal view em Empodium IG Internal female genitalia LO Lateral view of annuli LI Leg I PM Lateral view of posterior opisthosoma. Scale bar: $15 \mu \mathrm{m}(\mathbf{D}) ; 10 \mu \mathrm{m}(\mathbf{A L}$, CG, IG, PM); $7.5 \mu \mathrm{m}(\mathbf{L O}) ; 5 \mu \mathrm{m}(\mathbf{L I}) ; 2.5 \mu \mathrm{m}(\mathbf{e m})$. 
(12-14); genu 5 (4-5), antaxial genual setae $\left(l^{\prime}\right) 25$ (23-26); tibia 6 (6-7), paraxial tibial setae $(l) 7$ (7-8), located in the middle; tarsus 7 (6-7), setae $f t^{\prime} 15$ (14-15), setae $f t^{\prime \prime} 22$ (20-22), seta $u^{\prime} 4$ (4-5); tarsal empodium (em) 6 (5-6), simple, 5-rayed, tarsal solenidion ( $\omega) 7$ (7-8), rod-like. Leg II 25 (24-26), femur 7 (7-8), basiventral femoral setae (bv) 13 (13-14); genu 5 (4-5), antaxial genual setae $\left(l^{\prime \prime}\right) 8$ (8-10); tibia 5 (4-5); tarsus 7 (6-7), setae $f t^{\prime} 6(6-7)$, setae $f t^{\prime \prime} 23(23-25)$, seta $u^{\prime} 4$ (4-5); tarsal empodium (em) 6 (5-6), simple, 5-rayed, tarsal solenidion ( $\omega$ ) 9 (9-10), rod-like. Opisthosoma dorsally arched, 64 (63-66) dorsal annuli, 63 (61-64) ventral annuli; microtubercles on the rear margin of the annuli, elliptical on the anterior part of dorsal annuli, linear and spiny on the posterior part of dorsal annuli and posterior part of ventral annuli, circular on the anterior part of ventral annuli. Setae c2 25 (25-27) on ventral annulus 9 (8-9), 47 (40-49) apart; setae $d 65$ (58-67) on ventral annulus 19 (18-21), 37 (34-37) apart; setae $e$ 12 (12-14) on ventral annulus 32 (30-32), 20 (20-21) apart; setae $f 29$ (29-32) on 6th ventral annulus from rear, 21 (19-21) apart. Setae $h 1$ absent, h2 71 (69-74). Genital coverflap 11 (11-12), 22 (21-22) wide, coverflap with two rows of ridges, the basal one with 12 (11-13) longitudinal ridges, the other one with 9 (8-10) longitudinal ridges, proximal setae on coxisternum III (3a) 17 (17-20), 17 (17-18) apart.

MALE. Unknown.

Type host plant. Rosa beggeriana Schrenk ex Fisch. \& C. A. Mey. (Rosaceae).

Relation to the host plant. Vagrant on leaves; no apparent damage was observed.

Type locality. Gongliu county, Xinjiang Uygur Autonomous Region, China (4309'37"N, 81³6'34"E), elevation 1,396 m; 3 August 2014, coll. Ji-Wei Li.

Type material. Holotype: female (slide number SHZU Paracolomerus 1.1, marked Holotype). Paratypes: 6 females mounted on 6 separate microscope slides.

Etymology. The specific designation gonglius comes from the name of location, Gongliu, where the new species was collected.

Differential diagnosis. All traits are in accordance with the type species Paracolomerus casimiroae Keifer, 1975 of the genus Paracolomerus (opisthosomal annuli subequal, legs with usual series of setae, scapular tubercles on rear shield margin, scapular setae projected posteriorly) except for ventral surface ornamentation of coxa I (lines do not circle around tubercles $1 a$ and meet at sternum in $P$. gonglius sp. n.; lines originate at setae $1 b$, circle distally around tubercles $1 a$ and meet at sternum, enclose most of the coxal surface in $P$. casimiroae).

This species is similar to P. fopingacer Xue, Song \& Hong, 2011, from Acer sp. L. (Aceraceae), but can be differentiated from the latter by median line almost complete, with 5-6 short lines on the lateral sides of prodorsal shield (median line present for half, without short lines on the lateral sides in $P$. fopingacer), frontal shield lobe absent (frontal shield lobe acuminate in $P$. fopingacer) and 5-rayed empodium (6-rayed empodium in $P$. fopingacer).

Remarks. To date, only three species were reported from the genus Paracolomerus, P. casimiroae Keifer, 1975, P. davidiae Kuang \& Hong, 1995 (in Kuang 1995) and P. fopingacer. 


\section{Subfamily Phyllocoptinae Nalepa, 1892 \\ Tribe Phyllocoptini Nalepa, 1892 \\ Genus Phyllocoptruta Keifer, 1938}

\section{Phyllocoptruta beggerianae sp. $\mathrm{n}$.} http://zoobank.org/D33691AE-25DD-4A17-A854-E7C9925C96FF

Fig. 3

Description. FEMALE ( $\mathrm{n}=9)$. Body fusiform, 207 (182-207, excluding gnathosoma), 49 (46-51) wide, 43 (40-46) thick; white. Gnathosoma 28 (27-30), projecting obliquely down, pedipalp coxal setae (ep) 3 (2-3), dorsal pedipalp genual setae (d) 9 (8-9), unbranched, cheliceral stylets 26 (25-27). Prodorsal shield 42 (40-43), 43 (41-44) wide, median line formed by lined short lines, admedian lines complete and connected posteriorly, submedian lines present at the posterior half, with several short lines and granules; frontal shield lobe rounded, broad-based, 5 (4-5). Scapular tubercles ahead of rear shield margin, 23 (22-25) apart, scapular setae $(s c) 16$ (16-18), projecting forward and convergent. Coxigenital region with 9 (7-9) microtuberculated semiannuli. Coxal plates with several short lines and granules, anterolateral setae on coxisternum I (1b) 11 (10-11), 12 (11-12) apart, proximal setae on coxisternum I (1a) 27 (26-31), 10 (9-10) apart, proximal setae on coxisternum II (2a) 46 (42-46), 25 (23-25) apart, tubercles $1 b$ and $1 a$ apart 7 (6-7), tubercles $1 a$ and $2 a$ 9 (8-9) apart. Internal coxisternal apodeme 3 (3-4). Legs with usual series of setae. Leg I 36 (35-37), femur 10 (9-10), basiventral femoral setae (bv) 14 (13-15); genu 5 (4-5), antaxial genual setae ( $l$ ) 22 (22-25); tibia 8 (8-9), paraxial tibial setae (l) 12 (10-12), located at $1 / 3$ from dorsal base; tarsus 9 (8-9), setae $\mathrm{ft}^{\prime} 19$ (19-21), setae $\mathrm{ft}^{\prime \prime}$ 22 (22-25), seta $u^{\prime} 10$ (9-10); tarsal empodium (em) 8 (7-8), simple, 8-rayed, tarsal solenidion $(\omega) 10$ (9-10), rod-like. Leg II 29 (28-30), femur 8 (8-9), basiventral femoral setae $(b v) 16$ (15-16); genu 4 (4-5), antaxial genual setae $\left(l^{\prime \prime}\right) 8$ (6-8); tibia 5 (5-6); tarsus 8 (7-8), setae $f^{\prime} 9$ (8-10), setae $f^{\prime \prime} 23$ (23-25), seta $u^{\prime} 9$ (8-9); tarsal empodium (em) 8 (7-8), simple, 8-rayed, tarsal solenidion ( $\omega) 10$ (9-10), rod-like. Opisthosoma dorsally with a furrow in the middle; 35 (33-38) dorsal annuli, elliptical microtubercles on the rear margin; 74 (72-77) ventral annuli, microtubercles on the rear margin, circled on the anterior ventral annuli, and linear and spiny on the last posterior ventral annuli. Setae $c 228$ (25-28) on ventral annulus 14 (12-14), 47 (45-48) apart; setae $d 52$ (48-52) on ventral annulus 28 (27-29), 35 (32-35) apart; setae $e 33$ (33-36) on ventral annulus 49 (47-51), 13 (12-14) apart; setae $f 28$ (26-29) on 6th ventral annulus from rear, 16 (16-17) apart. Setae h1 4 (3-4), h2 77 (75-83). Genital coverflap 13 (11-13), 19 (18-20) wide, coverflap with 3 transverse lines basally, 11 (11-13) longitudinal ridges distally, proximal setae on coxisternum III (3a) 43 (41-44), 15 (14-15) apart.

MALE ( $\mathrm{n}=2)$. Similar in shape and prodorsal shield arrangement to female, 155-169. Prodorsal shield 32-35, 28-31 wide; scapular setae sc 16-17, 21-23 apart. Opisthosoma dorsally with a furrow, 32-37 annuli, ventrally with 74-81 annuli, dor- 

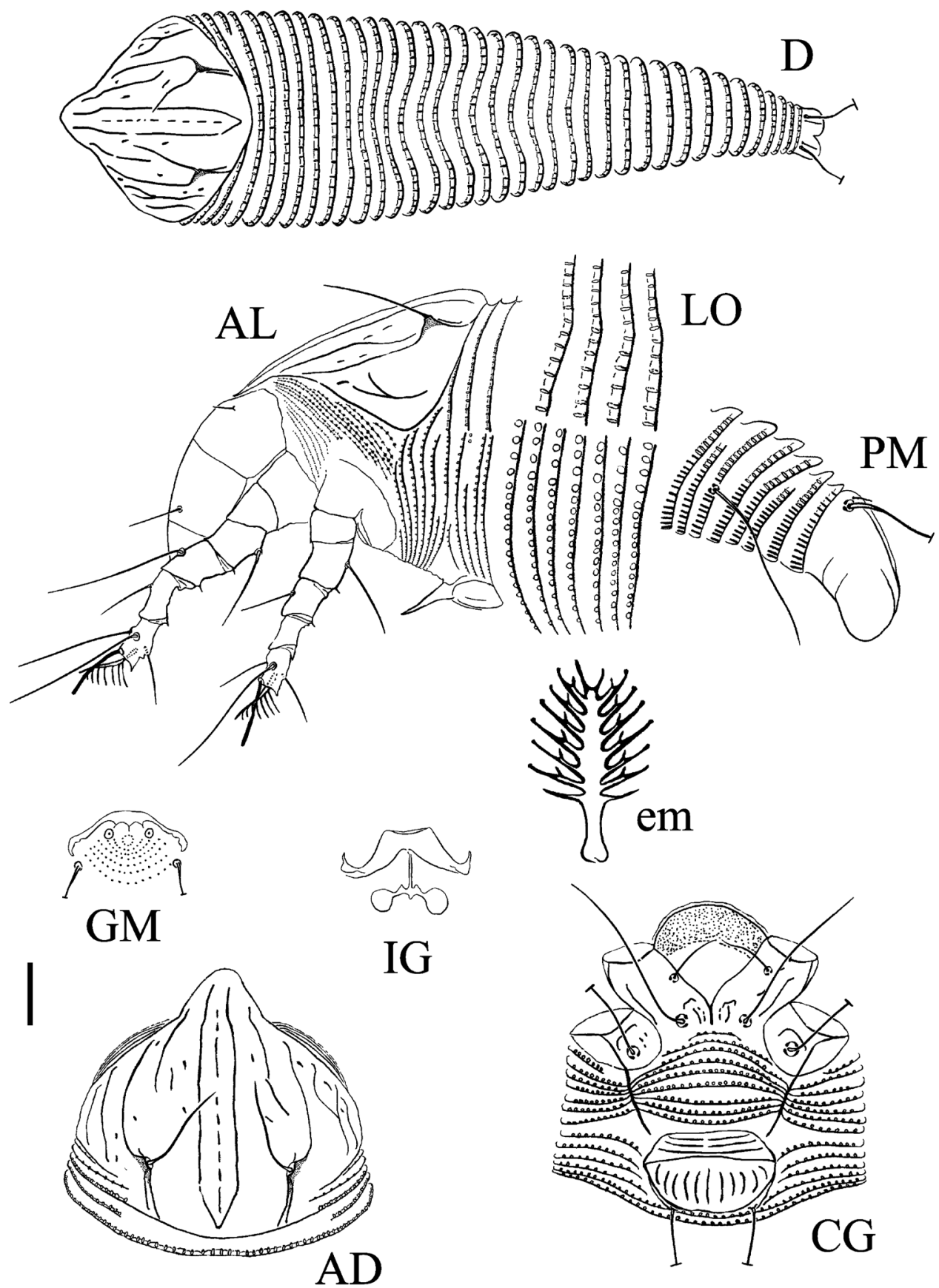

Figure 3. Schematic drawings of Phyllocoptruta beggerianae sp. n.: AL Lateral view of anterior body region AD Dorsal view of anterior body region CG Female coxigenital region D Dorsal view em Empodium GM Male genital region IG Internal female genitalia LO Lateral view of annuli PM Lateral view of posterior opisthosoma. Scale bar: $15 \mu \mathrm{m}$ (D); $10 \mu \mathrm{m}$ (AD, AL, CG, IG, GM, PM); $7.5 \mu \mathrm{m}$ (LO); $2.5 \mu \mathrm{m}(\mathbf{e m})$. 
sal and ventral microtubercles are similar to females. Male genitalia 17- 18 wide, setae 3a $18-20,14-15$ apart.

Type host plant. Rosa beggeriana Schrenk ex Fisch. \& C. A. Mey. (Rosaceae).

Relation to the host plant. Vagrant on leaves; no apparent damage was observed.

Type locality. Xinyuan county, Xinjiang Uygur Autonomous Region, China (4336'29"N, 82¹7'56"E), elevation 758 m; 29 July 2014, coll. Ji-Wei Li.

Type material. Holotype: female (slide number SHZU Phyllocoptruta 1.1, marked Holotype). Paratypes: 16 females and 2 males mounted on 18 separate microscope slides.

Etymology. The specific designation beggerianae comes from the epithet of the host plant, beggeriana.

Differential diagnosis. This species is similar to Phyllocoptruta clematoclethra Xue, Song \& Hong, 2010, from Clematoclethra sp. Maxim. (Actinidiaceae), but can be differentiated from the latter by admedian lines connected posteriorly (admedian lines separate in $P$. clematoclethra), scapular tubercles ahead of rear shield margin, scapular setae 16-18 (scapular tubercles on rear shield margin, scapular setae 3-4 in P. clematoclethra), female genital coverflap with 3 transverse basal lines (coverflap without transverse lines in $P$. clematoclethra) and 8-rayed empodium (5-rayed empodium in $P$. clematoclethra).

\section{Family Diptilomiopidae Keifer, 1944 \\ Subfamily Rhyncaphytoptinae Roivainen, 1953 \\ Genus Rhyncaphytoptus Keifer, 1939}

\section{Rhyncaphytoptus fuyuniensis sp. $\mathbf{n}$.}

http://zoobank.org/CE644BB3-52C6-43E6-AAC7-06BC248177F7

Figs 4-5

Description. FEMALE ( $\mathrm{n}=8$ ). Body fusiform, 256 (216-267, excluding gnathosoma), 60 (55-64) wide, 58 (54-62) thick; light yellow. Gnathosoma 61 (55-64), projecting downwards, pedipalp coxal setae (ep) 3 (2-3), dorsal pedipalp genual setae (d) 7 (6-7), unbranched, cheliceral stylets 83 (76-88). Prodorsal shield 29 (28-30) excluding the thin anterior process length from frontal lobe, 47 (46-49) wide, sub-triangular in anterior shape; long and flexible frontal lobe ending with a thin anterior process, the process extends for 14 (13-15). Median line very short, on 1/5 anterior part of prodorsal shield; admedian lines complete and connected at base with transverse lines, forming a vaseshaped outline; semicircled line between the scapular tubercles. Scapular tubercles ahead of rear shield margin, 30 (28-31) apart, scapular setae (sc) 47 (46-50), projecting forward. Coxigenital region with 15 (14-16) microtuberculated semiannuli. Coxal plates with 1-3 short lines, anterolateral setae on coxisternum I (1b) 10 (10-12), 10 (10-11) apart, proximal setae on coxisternum I (1a) 32 (29-33), 10 (10-11) apart, proximal setae on coxisternum II (2a) 45 (42-47), 29 (28-30) apart, tubercles $1 b$ and $1 a$ apart 7 (6-7), tubercles $1 a$ and $2 a 10(9-11)$ apart. Internal coxisternal apodeme 7 (6-7). Legs with 

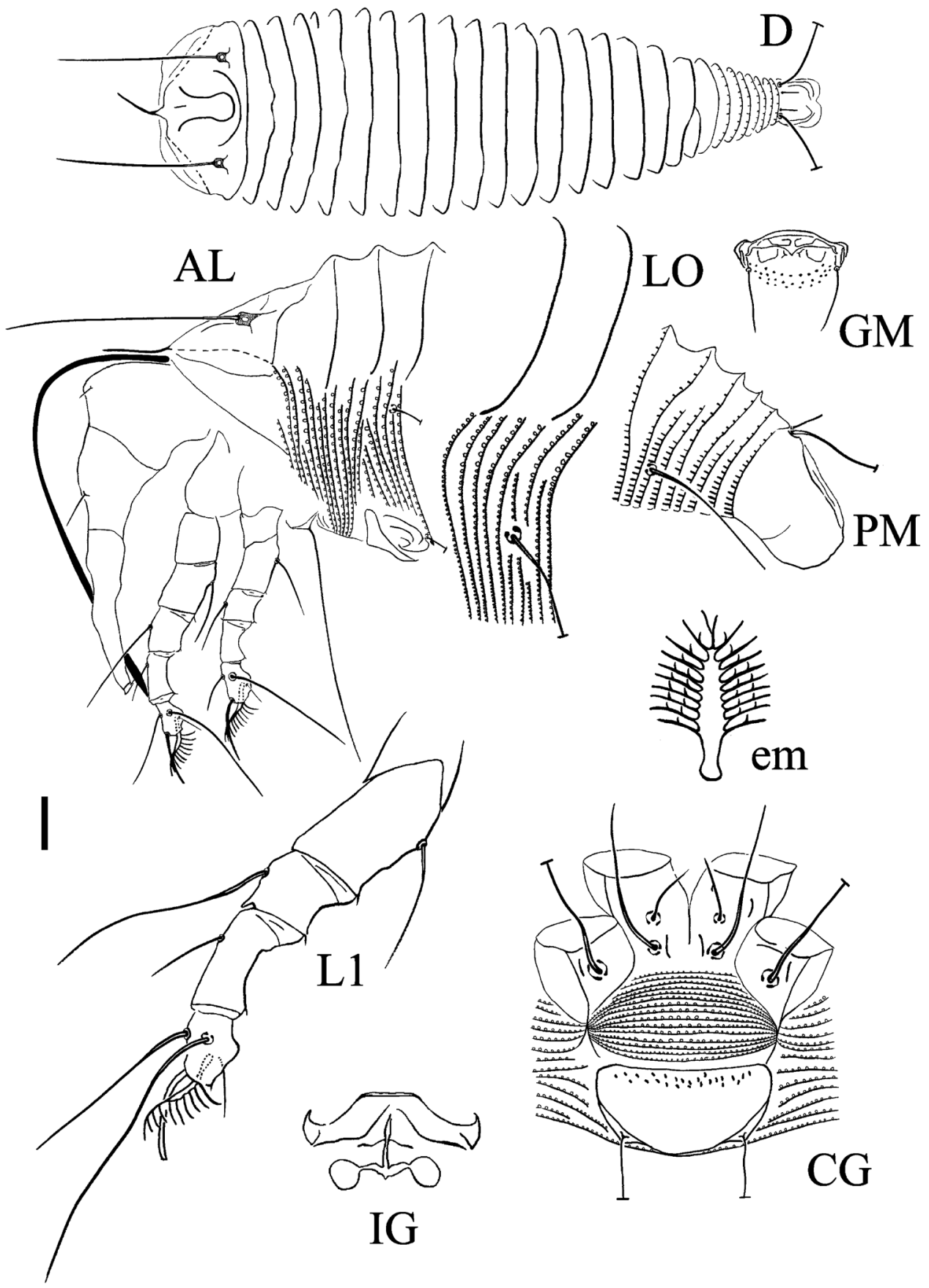

Figure 4. Schematic drawings of Rhyncaphytoptus fuyuniensis sp. n.: AL Lateral view of anterior body region CG Female coxigenital region D Dorsal view em Empodium GM Male genital region IG Internal female genitalia LO Lateral view of annuli and setae $d \mathbf{L I}$ Leg I PM Lateral view of posterior opisthosoma. Scale bar: $15 \mu \mathrm{m}$ (D); $10 \mu \mathrm{m}$ (AL, CG, IG, GM, PM); $7.5 \mu \mathrm{m}$ (LO); $5 \mu \mathrm{m}(\mathbf{L I}) ; 2.5 \mu \mathrm{m}(\mathbf{e m})$. 

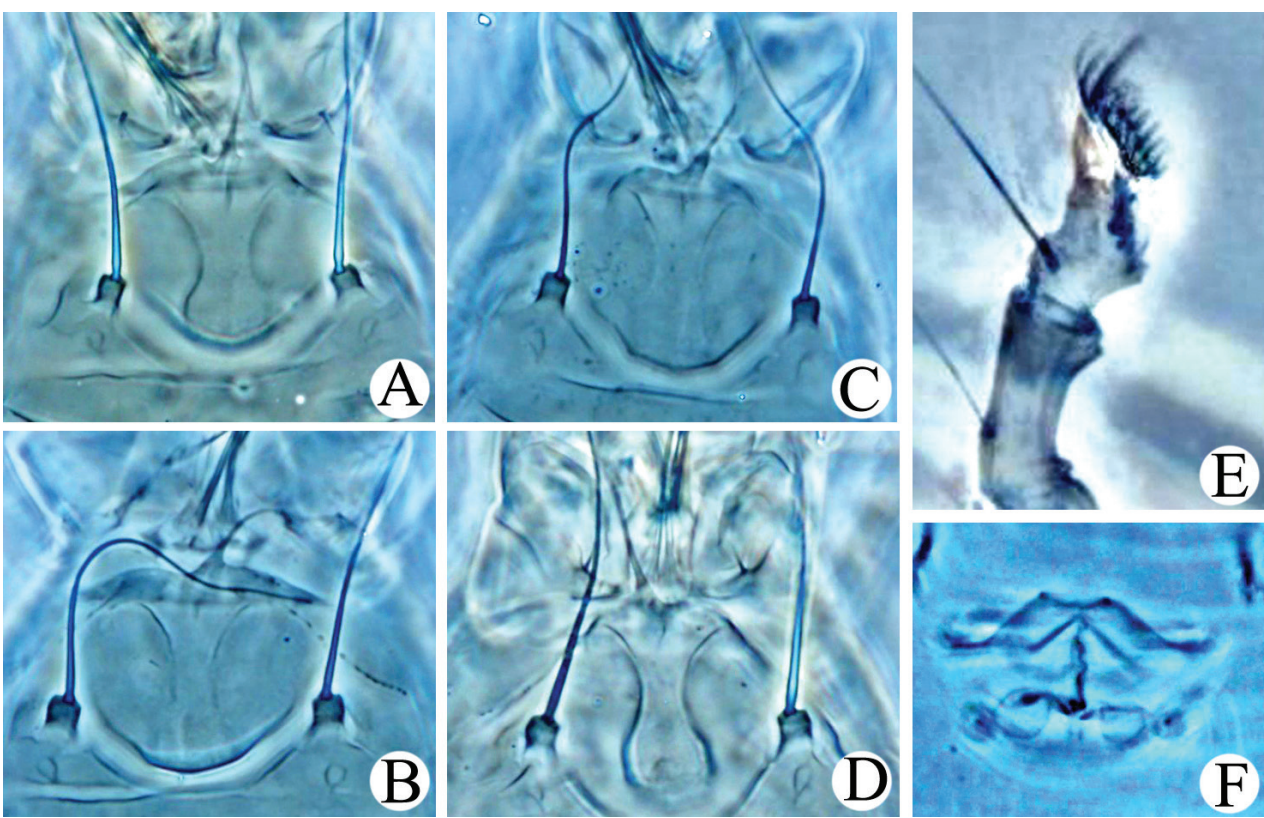

Figure 5. Rhyncaphytoptus fuyuniensis sp. n.: A-D Frontal lobe E Tibia and tarsus of Leg I F Female internal genitalia.

usual series of setae. Leg I 42 (41-43), femur 13 (12-14), basiventral femoral setae (bv) 13 (13-15); genu 7 (6-7), antaxial genual setae ( $\left.l^{\prime}\right) 23$ (23-25); tibia 10 (10-11), paraxial tibial setae $(l) 7$ (7-8), located at $1 / 3$ from dorsal base; tarsus 8 (7-8), setae $f t^{\prime} 20$ (18-20), setae $\mathrm{ft}^{\prime \prime} 26$ (23-26), seta $u^{\prime} 5$ (4-5); tarsal empodium (em) 8 (7-8), simple, 10-rayed, tarsal solenidion $(\omega) 8(8-9)$, rod-like. Leg II 39 (38-40), femur 13 (12-13), basiventral femoral setae (bv) 14 (14-16); genu 6 (5-6), antaxial genual setae ( $\left.l^{\prime \prime}\right) 9$ (9-11); tibia 8 (7-9); tarsus 8 (8-9), setae $f^{\prime} 10$ (9-11), setae $f^{\prime \prime} 30$ (26-30), seta $u^{\prime} 5$ (4-5); tarsal empodium (em) 8 (7-8), simple, 10-rayed, tarsal solenidion $(\omega) 10$ (10-11), rod-like. Opisthosoma dorsally arched, 25 (20-25) dorsal annuli, 92 (90-104) microtuberculated ventral annuli; the anterior dorsal annuli smooth (for about $5 / 6$ of them), the anterior ventral annuli with circled microtubercles (for about $2 / 3$ of them), the posterior part of dorsal and ventral annuli with linear and spiny microtubercles. Setae $c 213$ (12-14) on ventral annulus 19 (17-21), 59 (53-61) apart; setae $d 51$ (46-51) on ventral annulus 37 (36-42), 45 (41-45) apart; setae $e 26$ (26-29) on ventral annulus 55 (53-64), 25 (24-26) apart; setae $f 30(27-30)$ on 7 th ventral annulus from rear, 21 (20-22) apart. Setae h1 3 (3-4), h2 75 (70-79). Genital coverflap 15 (14-16), 30 (28-30) wide, coverflap with many granules basally, proximal setae on coxisternum III (3a) 14 (13-14), 20 (19-21) apart.

MALE $(n=5)$. Similar in shape and prodorsal shield arrangement to female, 202243. Prodorsal shield 22-25 without the frontal lobe length, 45-48 wide; scapular setae sc 40-46, 27-30 apart. Opisthosoma dorsally with 19-21 annuli; ventrally with 78-85 annuli, dorsal and ventral microtubercles are similar to females. Male genitalia 21-22 wide, setae 3a 12-13, 18-20 apart. 


\section{Type host plant. Cotoneaster ignavus E. L. Wolf (Rosaceae).}

Relation to the host plant. Vagrant on leaves; no apparent damage was observed.

Type locality. Fuyun county, Xinjiang Uygur Autonomous Region, China (47¹7'39"N, 8958'26"E), elevation 1,359 m; 15 August 2014, coll. Ji-Wei Li.

Type material. Holotype: female (slide number SHZU Rhyncaphytoptus 7.1, marked Holotype). Paratypes: 12 females and 15 males mounted on 27 separate microscope slides.

Etymology. The specific designation fuyuniensis comes from the name of location, Fuyun, where the new species was collected.

Differential diagnosis. This species is similar to Rhyncaphytoptus buxifoliae Song, Xue \& Hong, 2009, from Cotoneaster buxifolius Lindl. (Rosaceae), but can be differentiated from the latter by median line very short, on $1 / 5$ anterior part of prodorsal shield (prodorsal shield with incomplete median line on posterior $1 / 2$ in $R$. buxifoliae), scapular tubercles small (scapular tubercles 5-13 long in R. buxifoliae) and with a long and flexible frontal lobe (lack a distinct, long frontal lobe in $R$. buxifoliae).

\section{Acknowledgements}

This research was funded by the National Natural Science Foundation of China (No. 31460472 and No. 31172132). We thank Professor Ping Yan of the College of Life Science at Shihezi University for identifying host plants. We also thank Xiao Han of the Department of Entomology, Nanjing Agricultural University for their valuable suggestions on figure drawings.

\section{References}

Amrine JW Jr, Manson DCM (1996) Preparation, mounting and descriptive study of eriophyoid mites. In: Lindquist EE, Sabelis MW, Bruin J (Eds) Eriophyoid Mites: Their Biology, Natural Enemies and Control. World Crop Pests, 6. Elsevier Science Publishers, Amsterdam, Netherlands, 383-396. doi: 10.1016/S1572-4379(96)80023-6

Amrine JW Jr, Stasny TA, Flechtmann CHW (2003) Revised keys to world genera of Eriophyoidea (Acari: Prostigmata). Indira Publishing House, West Bloomfield, Michigan, U.S.A., 244 pp.

de Lillo E, Monfreda R (2004) 'Salivary secretions' of eriophyoids (Acari: Eriophyoidea): first results of an experimental model. Experimental and Applied Acarology 34(3-4): 291-306. doi: 10.1007/s10493-004-0267-6

de Lillo E, Di Palma A, Nuzzaci G (2002) Morphological adaptations of mite chelicerae to different trophic activities (Acari). Entomologica, Bari 35: 125-180.

de Lillo E, Craemer C, Amrine JW Jr, Nuzzaci G (2010) Recommended procedures and techniques for morphological studies of Eriophyoidea (Acari: Prostigmata). Experimental and Applied Acarology 51(1-3): 283-307. doi: 10.1007/s10493-009-9311-x 
Hong XY, Wang DS, Zhang ZQ (2006) Distribution and damage of recent invasive eriophyoid mites (Acari: Eriophyoidea) in mainland China. International Journal of Acarology 32(3): 227-240. doi: 10.1080/01647950608684466

Huang KW (2008) Aceria (Acarina: Eriophyoidea) in Taiwan: five new species and plant abnormalities caused by sixteen species. Zootaxa 1829: 1-30.

Keifer HH (1975) Eriophyiod studies C-10. U. S. Department of Agriculture, Agricultural Research Service, 24 pp.

Kuang HY (1995) Economic insect fauna of China, Fasc. 44 (Acari: Eriophyoidea) (I). Science Press, Beijing, China, 198 pp + plate 7 .

Kuang HY (1998) Three new species of the Phyllocoptinae from China (Acari: Eriophyoidea). Acta Zootaxonomica Sinica 41(4): 410-411.

Kuang HY, Pang HL (1997) Four new species of the Eriophyinae (Acari: Eriophyidae) from China. Entomotaxonomia 19(3): 230-234.

Kuang HY, Luo GH, Wang AW (2005) Fauna of Eriophyoid Mites from China (II) (Acari: Eriophyoidea). China Forestry Publishing House, Beijing, China, 176 pp.

Li JW, Li GY, Zhang JP, Xue XF (2014) Five new species of the genus Tetra Keifer (Acari: Eriophyidae: Phyllocoptinae) from Xinjiang Uygur Autonomous Region, China. Systematic and Applied Acarology 19(3): 329-352. doi: 10.11158/saa.19.3.7

Lindquist EE (1996) External anatomy and notation of structures. In: Lindquist EE, Sabelis MW, Bruin J (Eds) Eriophyoid Mites: Their Biology, Natural Enemies and Control. World Crop Pests, 6. Elsevier Science Publishers, Amsterdam, Netherlands, 3-31. doi: 10.1016/S1572-4379(96)80003-0

Lindquist EE, Sabelis MW, Bruin J (1996) Eriophyoid Mites: Their Biology, Natural Enemies and Control. World Crop Pests, 6. Elsevier Science Publishers, Amsterdam, Netherlands, $1-790$.

Lu SL, Mao CH (1990) Occurrence regularity and control techniques of Colomerus Vitis (Pagenstecher) in Xinjiang. Xinjiang Farm Research of Science and Technology (3): 18-20.

Oldfield GN (1996) Toxemias and other non-distortive feeding effects. In: Lindquist EE, Sabelis MW, Bruin J (Eds) Eriophyoid Mites: Their Biology, Natural Enemies and Control. World Crop Pests, 6. Elsevier Science Publishers, Amsterdam, Netherlands, 243-250. doi: $10.1016 /$ S1572-4379(96)80015-7

Petanović R, Kielkiewicz M (2010a) Plant-eriophyoid mite interactions: cellular biochemistry and metabolic responses induced in mite-injured plants. Part I. Experimental and Applied Acarology 51(1-3): 61-80. doi: 10.1007/s10493-010-9351-2

Petanović R, Kielkiewicz M (2010b) Plant-eriophyoid mite interactions: specific and unspecific morphological alterations. Part II. Experimental and Applied Acarology 51(1-3): 81-91. doi: 10.1007/s10493-009-9328-1

Skoracka A, Smith L, Oldfield G, Cristofaro M, Amrine JW (2010) Host-plant specificity and specialization in eriophyoid mites and their importance for the use of eriophyoid mites as biocontrol agents of weeds. Experimental and Applied Acarology 51(1-3): 93-113. doi: 10.1007/s10493-009-9323-6

Song ZW, Xue XF, Hong XY (2007) Four new species and a new name in the genus Rhyncaphytoptus Keifer (Acari: Eriophyoidea: Diptilomiopidae) from China. Zootaxa 1520: 57-68. 
Song ZW, Xue XF, Hong XY (2008) Eriophyoid mite fauna (Acari: Eriophyoidea) of Gansu Province, northwestern China with descriptions of twelve new species. Zootaxa 1756: $1-48$.

Song ZW, Xue XF, Hong XY (2009) Four new species of Rhyncaphytoptus from Tibet Autonomous Region, China (Acari: Eriophyoidea: Diptilomiopidae). Zootaxa 2196: 31-47.

Van Leeuwen T, Witters J, Nauen R, Duso C, Tirry L (2010) The control of eriophyoid mites: state of the art and future challenges. Experimental and Applied Acarology 51(1-3): 205-224. doi: 10.1007/s10493-009-9312-9

Wang HY, Lu SL (2004) One new species of the genus Tetra Keifer from China (Acari: Eriophyidae). Acta Zootaxonomica Sinica 29(2): 266-267.

Xue XF, Song ZW, Hong XY (2010) Review of Phyllocoptruta, with descriptions of two new species (Acari: Eriophyoidea). Annals of the Entomological Society of America 103(5): 697-705. doi: 10.1603/AN10019

Xue XF, Song ZW, Hong XY (2011) Three new species of Cecidophyinae (Acari: Eriophyidae) from China. Journal of Natural History 45(19-20): 1199-1211. doi: $10.1080 / 00222933.2011 .552804$

Xue XF, Han X, Song ZW, Hong XY (2012a) Eriophyoid mite fauna of Shaanxi Province, China, with descriptions of five new species (Acari: Eriophyoidea). Zootaxa 3292: 1-71.

Xue XF, Zhang JP, Li FL, Hong XY (2012b) A new eriophyoid mite species (Acari: Eriophyidae) infesting Haloxylon ammodendron and $H$. persicum (Chenopodiaceae) in Xinjiang Uigur Autonomous Region, northwest China. Systematic \& Applied Acarology 17(2): 202-209. doi: 10.11158/saa.17.2.6

Yang S, Jiao XD, Guo YL, Xu HX, Wang XQ, Zhang JP (2012) Occurrence regularity and control techniques of Tegolophus zizyphagus Keifer in Xinjiang. Northern Horticulture (08): 145-147.

Zang YC (1998) Damage investigation of Aceria pallida Keifer and Aculops lycii Kuang in Jinghe county, Xinjiang. Entomological Knowledge 35(3): 153-154. 